\title{
SUBSTANDARD VOCABULARY \\ IN THE SYSTEM OF URBAN COMMUNICATION
}

\section{Harlytska Tetiana ${ }^{1}$}

DOI: dx.doi.org/10.30525/978-9934-571-30-5_14

Abstract. The article is devoted to substandard elements which are
considered as one of the components in the system of urban forms of
communication. The Object of our research is substandard vocabulary,
the Subject is structural characteristics of the modern city language, the
Purpose of the study is to define the main types of substandard vocabu-
lary and their role in the system of urban communication. The theoretical
base of our research includes the scientific works of native and foreign linguists, which are devoted to urban linguistics (B. Larin, M. Makovskyi, V. Labov, T. Yerofeieva, L. Pederson, R. McDavid, O. Horbach, L. Stavytska, Y. Stepanov, S. Martos). Different lexical and phraseological units, taken from the Ukrainian, Russian and American Dictionaries of slang and jargon, serve as the material of our research. The main components of the city language include literary language, territorial dialects, different intermediate transitional types, which are used in the colloquial everyday communication but do not have territorial limited character, and social dialects. The structural characteristics, proposed in the article, demonstrate the variety and correlation of different subsystems of the city language. Today peripheral elements play the main role in the city communication. They are also called substandard, non-codified, marginal, non-literary elements or the jargon styles of communication. Among substandard elements of the city language the most important are social dialects, which include such subsystems as argot, jargon and slang. The origin, functioning and characteristics of each subsystem are studied on the material of linguistic literature of different countries. It is also ascertained that argot is the oldest form of sociolects, jargon divides into corporative and professional ones, in the structure of slangy words there are common and special slang. Besides, we can speak about sociolectosentrism of the

${ }^{1}$ Candidate of Philological Sciences,

Senior Lecturer at Department of the English Language and Methods, Kryvyi Rih State pedagogical University, Ukraine 
native linguistics and linguemosentrism of the English tradition of slang nomination. Except social dialects, the important structural elements of the city language are also intermediate transitional types, which include koine, colloquialisms, interdialect, surzhyk, pidgin and creole. Surzhyk can be attributed to the same type of language formations as pidgin and creole because these types of oral speech were created mostly by means of the units mixing of the obtruded language of the parent state with the elements of the native languages.

\section{Introduction}

The scientific novelty of the article is stipulated by the necessity of complex analysis of speech of different groups of the Ukrainian, Russian and American city population, which has been growing rapidly for the last scores of years. The city as the cultural and social phenomenon develops specific model of language behavior and predicts verbal activity of its inhabitants, which is traditionally connected with frequent usage of jargon, so the problem of occurring and functioning of substandard vocabulary is very actual nowadays. That is why the Purpose of the study is to define the main types of substandard vocabulary and their role in the system of urban communication. The main tasks of our work are: to classify the main types of the city language; to analyze the history and the reasons of appearing of individual types of city language; to compare the peculiarities of the Ukrainian, Russian and American city language. Structured and well-developed city language is an important factor of the nation's language existence. So the problem of the city language is being projected on the paradigm of the communicative power of literary language, which is strongly influenced by the peripheral forms of language. The question of peripheral (or intermediate) forms in the system of urban communication was raised in the scientific works of such native and foreign linguists as O. Horbach, S. Martos, L. Masenko, L. Stavytska, O. Bondaletov, M. Kytaihorodska, L. Krysin, O. Yerofeieva, Y. Khomiakov, L. Labov, R. McDavid, M. Gordon, E. Partridge, P. Trudgill etc. The methodological base is the statement about polyparadigmal existence of scientific paradigms with domination of system-structural and anthropocentric ones. The main methods are: the comparative method, the method of quantitative analysis and the method of dispersive factor analysis. 


\section{Harlytska Tetiana}

\section{The main components of the city language}

The city as the cultural and social phenomenon generates a specific model of language behavior and predicts verbal activity of inhabitants, which is traditionally connected with phenomenon of wide jargon usage. But we can certify that in the big city centers a complete existence of living forms of colloquial speech is absent, and if on the beginning of the previous century the society had the task to cherish the hothouse plant from language so now the root of language problems consists in the need to reconstruct the natural elemental forms of language existence.

After studying some theoretical and practical material we have convinced that the language of any modern city consists of the next components: 1) literary language with many functional types, in which colloquial speech has a specific place; 2) territorial dialects; 3) different intermediate / peripheral types, which are used in the colloquial speech but do not have territorial limited character (koine, colloquial words, interdialect, surzhyk, pidgin, creole); 4) social dialects (slang, professional and corporative jargons, argot). Such classification demonstrates variety and connections of different subsystems of the city speech, which have changed their linguistic and social nature under the influence of the modern conditions. For instance, the literary language of the $19^{\text {th }}-20^{\text {th }}$ centuries was considered as the integral foundation, but today it is divided into two independent kinds bookish and colloquial. The territorial dialects, which are influenced by strong differentiation in the city surrounding and are leveled by the literary language, do not exist in clear shape, because intermediate formations get more extension, combining features of dialect, literary language and colloquial words. Among the social dialects some corporative jargons lost the social base of their existence, but different kinds of professional jargons got the development instead.

Literary language with its national-colloquial variant is the main body, the fundamental principle of every language, though in Anglo-American tradition, especially concerning modern literary languages, we can find another term - language standard or standard language. As we know, in the definition of literary language the central notion is the norm. The norms of language standard exist on all language levels - phonetic, morphological, syntactical, lexical, but in the city conditions these norms are influenced by a great impairing, because it is absolutely evident that city promotes collision and interplay of different dialectal speech elements, dialects' mixing. 
If in the village only one dialect stands against literary language, but in the city this is a whole dialectal system, and its components remain in changeable relations. That is why standards and unification of literary language (especially in the city conditions) are very relative, because it is a very dynamic system, which has a mechanism of enrichment, replenishment and development and it is subjected to the influence of other idioms, which are on the periphery of the language system. So we have to speak about heterogeneous character of majority of modern literary languages, in particular Ukrainian, Russian and English.

The new forms of social life, radical changes in the functioning of mass media promoted joining to public communication of many carriers of literary language, colloquialisms and different dialects. But it is not worth exaggerating of territorial dialects' meaning in the city surrounding, because their carriers are only those speakers who came to the city from villages, but, being influenced by literary language and other city linguemes, the territorial dialects assimilate with them or exist in the natural form only in the boundary of a separate family.

The mastering of the new communicative spheres, their appropriate norms and language behavior and functional types are mostly determined by the extension of oral spontaneous communication's boundaries, especially in those situations, which were earlier served by written speech. So, today peripheral elements, which are also called non-literary, non-codified, marginal, substandard units or jargon styles of intercourse, are the most important in the city communication.

\section{Substandard elements of city communication}

Today peripheral elements play the main role in the city communication. Considering the fact that social factor in the city is more important than territorial one we accent on the social dialects, which are the most numerous forms of the city language. But it is worth noticing, that in the English-speaking, European and native linguistic literature the comprehension and interpretation of social dialect differ. American linguists (L. Labov, R. McDavid, L. Milroy, M. Gordon) study social language variants mostly on the phonetic and grammatical levels, and the main factors, which influence their forming, are considered to be social class and speaker's status. R. McDavid defines social dialect as acceptable in the particular society language sub-variant, which by virtue of some social forces is typical for 


\section{Harlytska Tetiana}

individual ethnic, religious and economic groups and groups of individuals with certain educational level and type [4, p. 365]. The author thinks there is no society without any social dialects, moreover, the less local class barriers the harder to find proper class differentiations, especially in speech.

For the last ten years the notion "sociolect" also got a wide expansion in European countries, especially Germany (H. Glinz, G. Heike, H. Steger, $\mathrm{R}$. Wodak), because models of stratification in modern languages begin to acquire bigger meaning than those ones, which have a public distribution of work as the base.

In the native linguistics social dialect (sociolect, social patois, social language variant) is considered as the kind of language, which is characterized by its usage in the limits of special social group (class, professional, age etc.) [5, p. 205]. The general feature of all language formations, which belong to social dialects, is a limitedness of their social base, because, appearing in response to different professional and group needs of particular associations, social dialects always coexist with other forms of language existence, which are always the basic ones, but social dialects are their additional forms. Concerning proper Ukrainian sociolects their origins come to the $17-18^{\text {th }}$ centuries, but Ukrainian sociolinguistic studies become popular only in the early 90 s of the $20^{\text {th }}$ century and the main works in this field belong to L. Stavytska, O. Selivanova, S. Martos, L. Masenko, who describe Ukrainian social dialects deeply and in detail.

\section{Social dialects}

Most linguists traditionally define such sociolects as argot, jargon and slang, but even nowadays there are some debates as to the lines of demarcation and definitions of these sociolectic components. The confusion in efforts to classify these elements is caused by migration processes of some lexical units from one group to another and facilitating other connotations or meaning nuances. It is also worth noticing that the fixed terms (argot, jargon, slang, ofeni etc.), which were found on the initial level of sociolects' appearing, do not correspond with modern vision and interpretation, besides each country has its own history of forming of any language phenomenon, among them social dialect is not an exception, so we can observe a branched system of terms, depending on the place and time of functioning of a certain sociolect. 
The oldest form of sociolects is argot, which can be called a specific code feature of a group, a password, which gives the feeling of community, because argot is interpreted as artificially created patois of any closed social or professional group, unknown for the strangers [9, p. 31]. The term "argot" is synonymic to "jargon", because they both have French origin and can be used on denotation of a special social or professional ramification from the nationwide language, but we consider argot in the narrower comprehension as the language of the "social bottom", declassed and antisocial elements (racketeers, thieves, beggars, vagrants, card players etc.). The appearing of this kind of sociolect is connected with feudal period in the language history, when there existed close corporations of craftsmen, wandering tradesmen, beggars etc., who created special language sub-codes to protect themselves, to be separated from the rest of society and to save their professional secrets, so the destruction of natural feudal farms, the strengthening of economic relations and appearing of the first cities, which caused bigger social mobility of inhabitants, became the main impulse for argot appearing.

The oldest argot systems in Europe are French Argot ("jargon”) and German Rorwelsch ("spoilt language"), which were fixed in the $13^{\text {th }}$ century. A very violent development of argot was observed in the $14-15^{\text {th }}$ centuries, which was caused by the Centenary War (a military-political conflict between the English and French Kingdoms (1337-1457)), its events undermined social-economic regime and caused the destruction of peasants and craftsmen, which stimulated the appearing of many criminal and beggarly groups, which cultivated argot.

In the USA argot was created by different social groups, which had the need and wish to have their own vocabulary, unintelligible to other people. Before the Civil War criminal argot existed in the USA, and it went back to the British one. In 1929 many criminals were expatriated from London as the result of reforming of the police system, and most of them found a shelter in the USA. During the Civil War a specifically American criminal argot started appearing, which in 1970 became to prevail over less diverse and expressive English argot. A "dry law" of 1920-s brought a great prosperity of bootleggers and gangsters, who even got some prestige, and mass producing of gangster films caused excessive propaganda of criminal argot of this surroundings all over the world. Besides, as opposed to the European argot, American one has national character proper. 


\section{Harlytska Tetiana}

In Russia in the $18^{\text {th }}$ century, except criminal argot, there were also conditionally professional argot of corporative craftsmen, small merchants and peasants, for example, ofeni of Volodymyrska province. In 80-90s of the $20^{\text {th }}$ century, while studying the language of Moscow inhabitants, V. Yelistratov used the term "Moscow (city) argot" (алтынник - greedy-guts, skinflint, huckster; безиковать - to take a risk in a card game; жжёнка, жжёночка - a drink made from burnt cognac or rum with sugar, fruit and spices, ляпинка - a free hostel for students, built by Liapins the merchants [3]). In his conception we can find the bond of argot and city culture, because argot is not just a social dialect, it is the interactional unit of language and culture [3, p. 595]. The author is convinced that each person has his own argot, and there are also thousands, tens and hundred thousands of different argot, which have distinct, determinate borders neither in time, nor in space and social hierarchy.

In the history of the Ukrainian language first reliable data about argot existing refer to the $16-17^{\text {th }}$ centuries, when lyrists organized the insurgencies and created their vocabulary for common understanding. In the $17^{\text {th }}$ century seminary and pupilary argots appeared, and they were connected with the insurgencies of fraternal schools and seminaries. But if a lexical base of ancient professional argot, in particular beggary-lyre, was dialectal speech of different regions, then attributing of criminal argot in Ukraine to the forms of Ukrainian language existing remains problematic. As an outstanding Ukrainian argot scientist O. Horbach says, while analyzing the city street and criminal argot on the territory of Ukraine we face one problem - the connections of this argot with the similar Slav languages Russian on the territory of ex-Russian Ukraine (Odesa, Kyiv, Kharkiv, Binnytsa, Dnipropetrovsk) and Polish on the territory of ex-Polish areas (Lviv, Ternopil, Drohobych, Stanislaviv) [2, p. 172]. And in 1996 a modern Ukrainian-speaking "Dictionary of criminal jargon" by O. Popovchenko was published as the proof of this process.

In the $20^{\text {th }}$ century argot broke up as the language phenomenon, but it has remained in some Russian regions (Briansk, Volodymyrsk) to the middle of the century. As for "jargon" it is some kind of a terminological example for defining argot and slang. In the encyclopedia "Ukrainian language" jargon is explained as one of the social dialects, which differ from customary language by using some specific expressively colored vocabulary, synonymic to the words of common usage, phraseology, and sometimes by 
special pronunciation [9, p. 31]. At opposed to argot jargon is opened and occurs among wide, mostly young speakers, who are united by the same interests, long existence in some area. Jargon is produced by social-psychological community of its carriers - mostly young people, who have emotional excessiveness, maximalism, their conception of life values, norms of behavior. Jargon is a symbol of appurtenance to particular social group and the index of its specific language existence, and the linguistic display of its subculture. We support V. Khymyk's thought who, considering jargon in a narrow comprehension, defines it as a half-opened lexical-phraseological subsystem which is used by a certain social group for the dissociation from the rest of language society [13, p. 13].

In linguistics jargon traditionally is divided into professional and corporative (group) jargons, but in the native and foreign traditions there are some differences in the notional apparatus and significative frames. So in the German linguistics corporative and group jargons are sometimes called Sondersprche, which is considered as a very wide term. German linguists combine in it arrogant pupils" "language", jargons of students, soldiers, sailors, doctors, lawyers etc.; besides, they replace the term "jargon" with the term "language" (for example, Penalersprach, Burschensprache, Studentensprache, Soldatensprache, Teenagersprache, Verbrechersprache) or "slang". In the Russian linguistics (O. Kozhyn, V. Kolesov, L. Skvortsov, T. Yerofeyeva) "professional jargons" are identified with the term "professional colloquialism", but we must notice that comparing with the Ukrainian language they are not so frequent and bright in the Russian language and are mostly connected with plant work (e.g. бродилка - ferment corporation on the beer plant; гильотина - machine-tool for paper cutting; жираф - crane; зарез - defective tool; ребро - an operation on the meat plant when meat and ribs are separated) military business (афганка - a kind of military uniform; воробей (запах, карась, мамонт) - a recruit soldier; залётчик - a military discipline disturber; трак - a cadet of tank school), computers (жимануть - to make a file archiving; краказябла - an e-mail symbol; пипка - a computer button) and sport (варяг - a player, who came to the team from another city; горчичник - a yellow precautionary card to a player; дома - on the native playground [8]). L. Krysin thinks that professional jargons in the linguistic sense are not homogenous and he defines in their structure the two groups of communicative means: means that coincide with the units of general national language and compose the 


\section{Harlytska Tetiana}

base of lexical and grammatical system of professional jargons; argot words and combinations, which partly duplicate officially accepted in a particular sublanguage terms, which partly name that thing, which does not have officially accepted terminological denotation [6, c. 69]. The author considers the figurative reinterpretation of the code words and phrases the distinctive feature of professional jargons.

In the American linguistics most scientists, including E. Partridge, G. Mencken, do not distinguish professional lexical systems and professional jargons, and in jargons they do not distinguish professional from corporative ones. Rather famous scientists of the English language T. Beliaieva and V. Khomiakov correlate professional jargon vocabulary of the Russian language with expressive slang of the English language, including evaluative words and phrases, which reflect certain group's attitude to the objects of labor and life; they are reduced duplets of terms, professionalisms, literary words and they get their significative essence by virtue of the neutral word's meaning, which they coexist with [1, p. 60]. These are the examples: hack - a journalist, professional writer; headshrinker - a psychiatrist, psychoanalyst; hit - killing, a professional murder; hit-man - a professional killer; hoofer - a professional dancer; $M A W$ - a glamorous or idle woman of uncertain profession, an abbreviation of "model, actress, whatever..."; trick cyclist - a psychiatrist [15].

In the Ukrainian linguistics to define professional jargons such terms are used as "professional sociolects" (L. Masenko), "professional jargon lexicon", "professional colloquialisms" (L. Stavytska), which are defined as figurative expressive, laconic words and phrases, which have neutral appropriate words and are used mostly in the everyday speech of people of a specific profession or occupation, united by the same interests, manners and social status [11, p. 50]. Among the rest of social dialects professional ones make the most difficult category for researching, because they are closed for detached onlookers. With the development and increasing of amount of modern professions the character and structure of professional dialects has also changed. So, one part of them belong to relatively opened social-professional groups (sportsmen, drivers, hairdressers, musicians, journalists, businessmen, realtors, computer men), and they are always "on ear"; relatively closed professional groups include market people, bankers, accountants, scientists, people with the same hobby, football fans, and the members of the family. Ukrainian professional jargonisms are very different, 
lively and metaphorical, a big amount of them are connected with gambling (ас-асе; вина (віна, вино, зелень, лік)-spade; жидок-a set in preference; жолудь (крайц) - clubs, кралька - queen); medicine (атак - an attack; б'ючка (живчик) - a pulse, заштрик - an injection); army (бити в дах to salute; запілля - rear; касарня - barracks); football (e.g.: баняк - a gate; бомба - a kind of hit; кальош - arbiter); tailor's business (рибка - a tuck; турнюра - a lining in women's clothes); music (весло - a guitar, дур a major key, кікс - a false note; моль - minor key); chess (бігун (гермак, паж, стрілець) - queen; вежа - a rook, лищар - a knight); cars (кіха - tyre, москаль - a car of "Moskvich" brand; спрягло - coupling) [14].

But lexemes of culinary and school life form the biggest part of professional jargon in Ukraine. Such a big number of culinary jargonisms characterizes Ukrainians as food lovers and affirms their timid attitude to food, because its price is a hard work, big efforts and tenacity, that is why culinary for Ukrainians is the art, which is much spoken about and professional jargon is a good tool in this process: ззаєць - a meat bread; кабаноси very thing smoked sausages; капуснячок - a patty with cabbage; корінняspices, москалик - marinated herring; юрашок - gingerbread [14]. And school speech is notable for its brightness, humor, irony, neatness and witticism, which is evident from the next examples: арімуватися - to have a walk with a girlfriend; баняк - unsatisfactory mark; буда - a school; дойча - German lesson; жид - an ink spot in the copybook; люфт - nonappearance; шахрайка - a crib; штубачок - a fool [14].

There is also another very important group of jargons - corporative (group) jargons, which are defined as socially stipulated variants of the national language, based on the people's separating according to social features, age, style of living, community of interests and some kinds which are not connected with professional activity [5, p. 50]. Corporative jargons appear in the surroundings of speakers from different subcultures. Group jargons' vocabulary is essentially different from professional one by its purpose. The forming of special professional vocabulary, as a rule, is stipulated by the necessity to denominate a thing or phenomenon, which the producer deals with in his activity. Group jargons' vocabulary denotes mostly well-known things, qualities, conditions. So we deal not with conceptual synonymous but with expressively estimative, mostly stylistically reduced synonymic formations. These lexical systems are distinguished by a high expressive level. The youth is characterized as the most active creator of corporative jargons. 


\section{Harlytska Tetiana}

In the Ukrainian and Russian city language the system of corporative jargons includes the jargon of pupils, students, artists, drug addict users, homosexualists, prostitutes, hopniks, scouts etc. (e.g., альфонс - a souteneur; втикати (втыкать) - to sniff acetone; зістрибнути (соскочить) to stop using drugs; цивіл (иивил) - a man who is not the member of hippie system; баян-a medical syringe [10, p. 10]). Their main feature is existence in their system a great deal of foreign vocabulary, especially English and American ones: блейз - a headgear with peak; блек - a Negro, a negroid representative; герл $а$ - a girl; дабл - a toilet; драйвер - a driver, a chauffeur; дрінк (дринк) - an alcoholic drink; коп - a policeman; крейзі (крейзи) insane; npaüc - money [10, p. 10]. In the city language of the USA for the last 20-40 years there were three youth jargons: beatniks' jargon was replaced by hippies' one, later punks' jargon appeared. It is also worth noticing that all these jargons express special protest against the establishment of the American society's commercialization and social injustice. These jargons' speakers do not have corporative diglossy, because they are characterized by contracted communicative loading and do not replace the literary language.

So the fundamental peculiarity of jargon is its social conditionality, that is why jargon is considered as the language formation based first of all on the social organization of people. We propose to consider jargon in two meanings: narrow (professional and corporative city languages) and wide - as the synonym of slang, which is defined as a special peripheral lexical layer, which is beyond the limits of both literary colloquial language and dialects of the national language and it includes, from one side, a specific lexical and phraseological layer of professional patois, social jargons and criminal argot, and, from the other side, the layer of wide-spread and obvious emotional-expressive vocabulary and phraseology of substandard speech. But it is also worth noticing that Ukrainian and Russian slang is not equivalent to the English-speaking countries' slang for a number of features, but wider approach in consideration of slang in foreign linguistics helps overcome the contradictions, caused by ontological for sociocentrism problem of delimitation of slang, argot and jargon.

In native linguistics slang is very often correlated with other sociolects: jargon and argot (S. Martos, L. Stavytska, P. Hrabovyi, Y. Mosenkis, L. Selivanova, I. Shchur). In the English linguistics slang is mostly explained as a kind of colloquial, informal, substandard language. So we 
can speak about sociolectocentrism of the native tradition of slang nomination and linguemocentrism (following V. Zhuravlov the term "linguema" is considered as the form of language existence) of the English one.

The term "slang" has the shortest history in the lexicology of the Ukrainian and Russian languages and it was borrowed from the English language. The study of slang in Soviet linguistics begins from the study of English stylistics in the 1960-s, but in the 1980-s the same researches were being practiced in the Russian language, which was caused by the recovery of substandard vocabulary's studying. A general influence of the English culture, which activated the attraction of foreign linguists' knowledge and expansion of English borrowings into recipient language, has facilitated this process in some way. That is why on the incipient phase of its functioning lexeme "slang" was used to denote lexical-stylistic means of the English language, and later its meaning was expanded and integrated to the terminological apparatus of the Ukrainian and Russian lexicology. In the foreign linguistics it is thought that slang occurred in the organization of different communities and serves for sustaining and changing of some social structures or power relations between social groups; it is also a necessary and inevitable cultural product of modern complicated, dynamic society.

In native linguistics there are some attempts to explain phenomenon of slang on the basis of social dialect. "The Encyclopedia of history of Ukrainians" gives the next definition of slang: city sociolect, which arose from argot of closed social groups (delinquents, shopkeepers, craftsmen, prisoners, seminarists-pupils, soldiers), as emotionally colored vocabulary of law and unceremonious style, which is widely spread among social lowest part of society and some age groups of the city (craftsmen, school youth) [7]. There are two important moments in this definition: at first, slang genetically is a city language; at second, slang is a reiterative formation comparing with other social dialects.

It will be a mistake to think that a sphere of slang functioning is just city lowest part of society, because the main social pragmatic aspect of slang is its usage in informal situations of oral speech. Among all sociolects slang is the most depressurized structure, so it minimum depends on the age qualification, social belonging and it remains in free movement in the colloquial speech. Slang shows more semantic potential of the word-expressive, the possibility to modify lexemes in context and to join word play. So slang can be called a quintessence of the colloquial language, which is 


\section{Harlytska Tetiana}

connected with life comfort but not with scientific laws, grammatical rules or philosophical ideas.

By its structure slang traditionally is divided into general and special. In native linguistics (L. Krysin, V. Kolesov, T. Yerofeieva, V. Khymyk, L. Masenko, L. Stavytska) to special slang they enlist professional and corporative jargons. In the English language special slang is studied not so good as general one, and most linguists (H. Antrushyna, I. Halperin, V. Viliuman, E. Partridge, H. Mencken) enlist to its structure argot, cant, rhyming slang, group jargons and professional patois, back slang etc. (e.g., adam and eve - to believe (rhyming slang); laugh and joke - a smoke (rhyming slang); amscray - scram, go away (backslang); ecaf - the face (backslang); lickin'stick - a sweetheart, favorite friend (black slang) [15]).

General slang (in the Ukrainian language its equivalents are jargon colloquial language, jargon vocabulary; in the English language - just slang) is considered as that layer of modern jargon, which is not an appliance of peculiar social groups, with sufficient frequency occur in the language of mass media and which is equally used by all inhabitants of a big city, especially educated carriers of literary language. For example, agro (agro) - aggravation; amped - excited or agitated; legless - drunk; ling a language; loaded - drunk; no-no - something forbidden; shoo-in - a certainty; tight - mean, stingy, miserly; ass-wipe - toilet paper [15] - in the English language; бабло - money; геморой - a problem or a hard work; дятел - a fool; здиміти - to disappear; квасити - to drink alcoholic drinks; кльово - very good; лажа - something of a bad value, unpleasantness; морозитися - to ignore; наворот - something very difficult for understanding; nузир - a bottle with alcohol [10] - in the Ukrainian language; банка - a car "Zaporozhets"; белка - delirium tremens; бульбаByelorussian; вертушка - a bus of circular route; волочь - to understand; грабли - hands; дыня - a head, a face; зеркала - eyes; касса - a purse; кинуть - to cheat someone; однохатка - a one-room flat [8] - in the Russian language.

\section{Intermediate transitional types of speech}

Except social dialects, intermediate transitional types of speech are also very important components of the city language. They include koine, colloquialisms, interdialect, surzhyk, pidgin and creole. City koine combines the elements of the literary language, territorial and social dialects, but it 
is oriented on the literary norms. Koine (from Greek koinos - general) initially was used only for generally Greek language, which was formed in IV-III centuries B.C. and it served as unatsry language of business, scientific and fiction of Greece before II-III centuries. In modern linguistics koine is considered as the common mean of communication of all aboriginal population, that combines different social and ethnic groups, and people who were born in the other places but have been socialized in this city. Koine can include different superdialectal forms of language - such as called interdialects, which combine features of different territorial dialects, - or one of languages, which is functioning in a given region. Koine's arising is a typical phenomenon of the language life of big cities, where there is especially intensive interaction of different dialectal elements, as the result there is a leveling of different dialectal distinctions. City inhabitants have a high level of sociocultural stratification, intensive social mobility, which distinguishes city culture from agrarian one. Intergroup communication in the city conditions demands from representatives of different professions and social classes to adapt their speech to general usage to guarantee successful communication. City koines appear in this way, and they are not just interdielectal form of everyday communication, but they also accommodate with other spheres of communication - courts, city government, folklore, that is why sometimes koine is called the intelligent "erudite" speech.

Very interesting from the scientific point of view it is such city lingueme as colloquialism, which can be explained as one of structural-functional types of native language, which, having no territorial or highly specialized limits, together with dialects and jargons is opposed to literary language, its colloquial style. Unlike koine speakers, colloquial speakers do not realize the peculiarities of their speaking, because colloquial speakers are those people who lost contact with their dialect, but do not adopt the literary language, so these are mostly migrants from villages. Colloquialisms can be found not just in Russian, but also in other languages, for example, français populaire - in French, umgangssprache - in German, dialetto regionale in Italian, obecna čestina - in Czech et cetera; in the English language sometimes we can find an equivalent "general colloquial words".

Social base of colloquialism is very varied. Initially its carriers were considered to be older city inhabitants, who did not have education. But the amount of people with the same social characteristics began to decrease, so, considering these changes, in the second half of the $20^{\text {th }}$ century some 


\section{Harlytska Tetiana}

scientists (L. Krysin, F. Filin, L. Kapanadze) started emphasizing two main types of modern colloquialism: colloquialism - 1 (social or non-literary colloquialism) - its carriers are old-aged citizens of peculiar social-cultural status, as a rule, with law level of education; colloquialism - 2 (functional stylistic) - its carriers are young and middle-aged citizens, who have not finished secondary education [6]. Besides, if earlier colloquialism was materialized only in oral form, now it has the reflection in fiction and printed mass media, which affirms the expansion of functional limits of this lingueme and modern authors' wish to influence the reader by means of appealing to ordinary citizen' speech. These are the examples of Russian colloquialisms: бакланить - to chat; ботало - a prattler; вельветки - shoes made of velveteen; дзынькать - to ring on the phone; запотрошить - to dun, to bore; курить - to have a rest; ломь - "L\&M" cigarettes; матюгаться to use foul language; нарезать - to go fast; продавить - to punch a ticket; простеикий - very simple; психушка - mental asylum [8].

The peculiarities of the Ukrainian colloquialism are the integral part of history and modern state of the Ukrainian language in general. It is, at first, relatively smaller (comparing, for example, with neighboring Russian language) distance between colloquialism and codified language, which is explained, from one side, by forming of new literary Ukrainian language on the native basis, and, from another side, - by its slow codification. These are the examples of Ukrainian colloquialisms: велике ай-вай - a sedate person; аквавіта - vodka; алилуйко - a deacon; амба - an impasse, the end; балабол - an irresponsible person; бігунець - a bedbug; весло - a guitar; викидайло - a porter in a restaurant; дотертися - to reach; забігайлівка a bar, a café; термінатор - a man who can drink a lot of alcohol; циганити to solicit [14]. So not always we can distinguish proper colloquial and literary colloquial units. At second, there is visible opportunity of territorial differentiation of colloquialism into Eastern-Ukrainian, Galician etc. At third, there is lack of "proper Ukrainian" city colloquialism, which is connected with domination of Russian language in most of Ukrainian cities of eastern and southern regions. At fourth, surzhyk (mostly Ukrainian-Russian) as a very visible feature of Ukrainian colloquialism.

Surzhyk formations get into other forms of language existence, in particular, colloquialism, as the result surzhyk carriers form numerous socially active layer of Ukrainian society, because surzhyk is one of the forms of language existence, which together with territorial and social 
dialects constitutes oral not codified sphere of speech communication of Southern and Eastern Ukraine. The main feature of surzhyk is combining of two languages (Ukrainian and Russian) with inobservance of language norms. The forming and development of surzhyk system in the Ukrainian language are connected with politics of russification, because in Soviet times the population of Ukraine had to conform to the Russian language, which took a prominent place in the official and unofficial speech of city inhabitants of the South-eastern Ukraine. In the 19-th century Kyiv language was smoothed and adapted to the Russian language, but finally it did not become Russian at all. Ukrainian language almost went out of use and became a village acquirement. Migration processes of village inhabitants caused a strengthening of a functional role of village surzhyk, which stratified onto the city one, and the russification of the 1970-s broke the language of Ukrainian village, which became surzhyk-speaking. Surzhykisation of the major part of Ukrainian inhabitants' speech by means of the Ukrainian and Russian languages mixing leads to the functional surzhyk's expansion and its gradual reforming into the main means of oral communication. These are the examples of Ukrainian surzhyk: безналічний cashless; винуватий - guilty; внедряти - to inculcate; гребішок - a comb; жжсога - heartburn; ізвращати - to misinterpret; кажеться - it seems; лікарство - medicine; насікомі - insects; обув - footwear; побіда a victory; предложення - a proposition; сочуствувати - to sympathize; иявітний - colored; щеббйонка - breakstone chips; ярко - brightly [12].

Surzhyk can be attributed to the same type of language formations as pidgin and creole because these types of oral speech were created as the result of fragmentary adoption and simplification on all levels of the parent state language and its mixing with the native language, which guarantees the communication in the paradigm of relations "master - servant". Such foreign researchers as D. Crystal, V. Vicente, N. Smith, F. Özüorçun determine pidgin as the secondary language, which was formed to facilitate the communication between groups of people with different languages and cultures in the process of their durable communication, connected with trade and colonization [16, p. 1]. Pidgin is a mixed sub-code, which is used as the mean of interethnic communication. Pidgins appeared in the cities and villages of Africa and America, in particular Jamaica, Haiti etc. These types of oral speech were created mostly by means of the units mixing of the obtruded language of the parent state (English, French, Spanish, Portuguese 


\section{Harlytska Tetiana}

or Holland) with the elements of the native languages and their functions were limited by the situations. The main features of pidgins are: the simplification on all language levels and the absolute vocabulary domination of the European languages. The next generation of speakers might convert pidgin into creole language, so it could be changed from the subsidiary mean of Europeans' communication with local inhabitants into the mean of local ethnic groups' communication. Pidgin could not be native language but creole could become native in the second generation which used pidgin.

\section{Conclusions}

1. The system of the city languages includes many different components. They are: literary language, territorial dialects, different peripheral intermediate types of speech and social dialects. But today peripheral (or substandard) elements play the main role in the city communication.

2. Considering the fact that social factor in the city is more important than territorial we accent on the social dialects, which are the most numerous forms of the city language. They are divided into argot, slang and jargon, having their own origins, special peculiarities and characteristics in the languages of different countries.

3. The oldest form of sociolects is argot, The term "argot" is synonymic to "jargon", because they both have French origin. jargon traditionally is divided into professional and corporative (group) jargons, in the Russian linguistics "professional jargons" are identified with the term "professional colloquialism". In the American linguistics most scientists do not distinguish professional lexical systems and professional jargons, and in jargons they do not distinguish professional from corporative ones. In the Ukrainian linguistics to define professional jargons such terms are used as "professional sociolects", "professional jargon lexicon”, "professional colloquialisms". The term "slang" has the shortest history in the lexicology of the Ukrainian and Russian language, because it was borrowed from the English language. Slang shows more semantic potential of the word-expressive, the possibility to modify lexemes in context and to join word play.

4. Very important components of the city language are also intermediate transitional types of speech, which include koine, colloquialisms, interdialect, surzhyk, pidgin and creole. City koine combines the elements of the literary language, territorial and social dialects, but it is oriented on the literary norms. Unlike koine speakers, colloquial speakers do not realize the 
peculiarities of their speaking, because colloquial speakers are those people who lost contact with their dialect, but do not adopt the literary language, so these are mostly migrants from villages. The main feature of surzhyk is combining of two languages (Ukrainian and Russian) with inobservance of language norms. Surzhykisation of the major part of Ukrainian inhabitants' speech by means of the Ukrainian and Russian languages mixing leads to the functional surzhyk's expansion. Pidgin and creole were created mostly by means of the units mixing of the obtruded language of the parent state (English, French, Spanish, Portuguese or Holland) with the elements of the native languages and their functions were limited by the situations.

5. The prospect of our research is to study substandard vocabulary and phraseology of different Ukrainian, Russian and American cities.

\section{References:}

1. Belyaeva T., Khomyakov V. (1985) Nestandartnaya leksika angliyskogo yazyka [Substandard vocabulary of the English language]. Leningrad: Leningrad University. (in Russian)

2. Horbach O. (2006) Argho v Ukrajini [Argot in Ukraine]. Lviv: Linguistic University NAN of Ukraine. (in Ukrainian)

3. Yelistratov V. S. (1994) Slovar'moskovskogo argo : materialy 1980-1994 gg. [The Dictionary of Russian argot: the material of 1980-1994-s]. Moskow: Russkie slovari. (in Russian)

4. McDavid R. I. (1975) Dialektnye i sotsial'nye razlichiya v gorodskom obshchestve [Dialectal and social differences in the city society]. New in linguistics, Vol. 7, pp. 363-381.

5. Kozhemyakina V.A., Kolesnik N.G., Kryuchkova T. B. (2006). Slovar'sotsiolingvisticheskikh terminov [Glossary of Sociolinguistic terms]. Moskow: Institut yazykoznaniya RAN. (in Russian)

6. Krysin L. P. (2003) Sovremennyy russkiy yazyk: sotsial'naya i funktsional'naya differentsiatsiya [Modern Russian language: Social and functional differentiation]. Moscow: Yazyki slavyanskoy kul'tury. (in Russian)

7. Kubijovych V. (1976) Encyklopedija Ukrajinoznavstva. Slovnykova chastyna [The Encyclopedia of history of Ukrainians]. Paris; New-York: molode zhyttja. (in Ukrainian)

8. Osipov B. I. (2003) Clovar'sovremennogo russkogo goroda : Ok. 11000 slov, 1000 idiomaticheskikh vyrazheniy [The Dictionary of modern Russian city : about 11000 words, 1000 idioms]. Moscow: Russkie slovari. (in Russian)

9. Rusanivskyi V. M., ed. (2004) Ukrajinsjka mova : Encyklopedija [Ukrainian language : Encyclopedia]. Kyiv: Ukrainian encyclopedia. (in Ukrainian)

10. Stavytska L. (2003) Korotkyj slovnyk zharghonnoji leksyky ukrajinsjkoji movy: Ponad 3200 sliv i 650 stijkykh slovospoluchenj [A short Dictionary of the Ukrainian jargon: More 3200 words and 650 idioms]. Kyiv: Krytyka. (in Ukrainian) 


\section{Harlytska Tetiana}

11. Stavytska L. (2001) Problemy vyvchennja zharghonnoji leksyky: Sociolinghvistychnyj aspekt [Problems of jargon vocabulary studying: sociolinguistic aspect]. Ukrainian language, Vol. 1, pp. 55-68.

12. Ukrajinsjkyj slovnyk surzhyka [The Dictionary of Ukrainian surzhyk]. Lviv, 1999-2018. URL: https://www.marazm.org.ua/document/surchik/ (Last accessed: 30.08.2018).

13. Khimik V. (2000) Poetika nizkogo, ili prostorechie kak kul'turnyy fenomen [Inferior Poetics or colloquialism as the cultural phenomenon]. S. Petersburg: Philological faculty of S. Petersburg State University. (in Russian)

14. Khobzej N., Simovych O., Jastremsjka T., Dydyk-Meush Gh. (2009) Leksykon ljvivsjkyj: povazhno i na zhart [Lviv lexicon: seriously and joking]. Lviv: Instytut ukrajinoznavstva im. I. Kryp'jakevycha NAN Ukrajiny. (in Ukrainian)

15. Thorne T. (2007) Dictionary of Contemporary Slang. London: A\&C Black Publishers Ltd.

16. Vicente V. (2007) English-based pidgins and creoles: from social to cognitive hypotheses of acquisition. Revista Virtual de Estudos da Linguagem. Vol. 5, no. 9, pp. 1-30. 